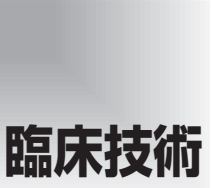

論文受付

2020 年 2 月 27 日

論文受理

2020 年 5 月 31 日

Code No. 751

\section{放射線治療装置の品質管理における， 光プローブ検出器を用いた光照射野幅と $X$ 線照射野幅の一致度の定量的評価}

\author{
下郷智弘 ${ }^{1}$ 奥平訓康 ${ }^{2}$
}

\author{
${ }^{1}$ 岐阜医療科学大学保健科学部放射線技術学科 \\ 2 名古屋大学医学部附属病院医療技術部放射線部門
}

\section{緒 言}

近年，X線による放射線治療では，治療装置に付属 した照合撮影装置等1) を用いて治療前に画像照合を行 うことが一般的になってきている 患者の動きや, 金属マーカ等を利用した体内臓器の動 きについても確認することが可能になってきてい る ${ }^{2,3)}$. しかしながら, 患者の初期位置の設定について は，レーザーポインタや光照射野が使用されることも 多く，これらの機器は患者の位置を決定するために，
未だ重要なツールである ${ }^{3,4)}$. 特に, 光照射野は患者の 治療位置が確定した後, 最終的なビームの入射位置の 確認として使用されることも多い。このため, 光照射 野はX 線照射野との幾何学的位置が一致している必 要があり，本邦における放射線治療品質管理ガイドラ イン ${ }^{5)}$ や米国医学物理学会 (American Association of Physicists in Medicine: AAPM)が推奨するガイドライ ン ${ }^{6.7)}$ においても，定期的に光照射野と X 線照射野の 一致性を評価するように推奨されている。現在, X 線

\title{
Quantitative Evaluation of Coincidence between Quantified Light Field Width and X-ray Field Width as Mechanical Quality Assurance
}

\author{
Tomohiro Shimozato $^{1 *}$ and Kuniyasu Okudaira ${ }^{2}$ \\ ${ }^{1}$ Department of Radiological Technology, Faculty of Health Science, Gifu University of Medical Science \\ ${ }^{2}$ Department of Radiological Technology, Nagoya University Hospital
}

Received February 27, 2020; Revision accepted May 31, 2020

Code No. 751

\section{Summary}

Aim: The aim of this work was to evaluate the coincidence between light and X-ray field width in air. Background: Light fields are often used for confirmation of irradiation position to superficial tumors and final confirmation of the patient's irradiation position. To guarantee collation by the light field, the light and X-ray fields must coincide. Currently, the light field width is determined mainly by visual evaluation using manual methods, such as use of graph paper and rulers. The light field width is difficult to visually recognize a definite position at the edge of the light field. Materials and Methods: We quantified the width of light fields emitted from a linear accelerator using a light probe detector and compared the results with those of X-ray fields. In-air measurements were conducted at the same position in the light field with the light probe detector and X-ray field using an ionization chamber installed in an emptied three-dimensional water phantom. Results: The radiation field in air was approximately $2 \mathrm{~mm}$ larger than the light field, and we found some influence of transmission and scattered rays on the penumbra region. Before and after exchanging crosshair sheets, the fields also exhibited differences in uniformity. Conclusions: The proposed method quantifies the light field using a photodetector and can be used to compare the light field with the X-ray field, conforming a useful tool for evaluating the accuracy of treatment devices in an objective and systematic manner.

Key words: light field, field width, quantification, light probe detector, quality assurance

*Corresponding author 
照射野についてはフィルムや放射線検出器等を使用し て確認することが可能であるが, 光照射野については 金尺定規やグラフ用紙等を用いた視覚的な評価を行っ ている. 更に, AAPM から出版されている Report No. $13\left(\right.$ TG-24) ${ }^{6)}$ や TG-45 ${ }^{8)}$, IEC (International Electrotechnical Commission) 60976 ${ }^{9)}$ によれば, 光照 射野と X 線照射野の一致性は, フィルムによって測 定するとの記載があり, フィルム法によって測定され た結果を AAPM Task Group 142(TG-142) ${ }^{7)}$ の提案す る許容值の範囲内であるかについて判断することを多 くの施設で行っている. しかしながら, IEC 609769) に記載されている放射線治療装置の照射野の幾何学的 設定表示值と光照射野幅とのわずかなズレを，視覚的 に評価することは困難である。光照射野については, グラフ用紙等の目盛り線と光照射野と影の部分の中線 のズレを評価するため, 測定者間誤差や測定間誤差を 誘発する。レギュラーフィルムを用いる場合は, 光照 射野のピン打ちされた位置や黒化度などによっても， 照射野幅の大きさは影響を受ける。

IEC $60976^{9)}$ や保守管理マニュアル ${ }^{10,11)}$ などでは，工 ネルギーが $6 \mathrm{MV}$ 以上の X 線照射野は標準治療距離 (Normal Treatment Distance: NTD) 100 cm における 標準測定深 (Standard Measurement Depth: SMD) 10 $\mathrm{cm}$ で評価するようにされており，エネルギーごとの $50 \%$ 線量幅を X 線照射野幅と規定している。特に, 水中において, $X$ 線照射野の測定位置と同じ位置にお ける光照射野の測定は, フィルム等の設置の困難さや 可視光の水中での屈折や乱反射による影響があり，両 者の照射野幅を直接比較し正確な一致度を評価するこ とは困難である。それゆえ, 固体ファントム上にフィ ルムを設置し, 投影された光照射野の位置を視覚的に マーキングされたフィルムの上に, 水等価厚 $10 \mathrm{~cm}$ の ファントムを載せて放射線を照射し, 光照射野と $\mathrm{X}$ 線照射野の一致度を評価している施設が多い. その際 に，フィルムをテープ等で固定したとしても，ファン トムを載せる際に位置ズレが懸念される。また, 光照 射野は視覚的に計測されるため, 検出器で精密に評価 された X 線照射野の各同一測定位置について正確に 比較することは困難である。

本研究では, 放射線治療装置の定期的な品質管理に 焦点を当て, 光プローブ検出器による光照射野と電離 箱線量計によるX 線照射野の同一位置における測定 を行い, 照射野幅の定量化法を調査し, 経時的な解析 の可能性を検討するために, 両者の照射野の比較評価 することを目的としている。この際に，IECの規定す る水中あるいは水等価ファントム内における照射野幅
を求めることを目的としていない. 光プローブ検出器 は水中下での使用を保証していないため, 光照射野の 測定を行う際は空中において評価を行った。同様の調 査は, 過去にJohnsen ら ${ }^{12)}$ によって行われたが, 光照 射野とX 線照射野の差が 1.5-2.0 mm 存在したという 結果であったが, 測定状況の同一性や照射野の違いに よる評価が曖昧なものであった，本研究では，複数の 幾何学的照射野について, 各照射野幅は, 軸外光量比 あるいは軸外線量比の半值幅 (full width at half maximum: FWHM)によって評価をすることで定量化し, 幾何学的照射野と光・X 線照射野とのズレ量, また光 照射野幅とX 線照射野幅の差を詳細に調查した。加 えて, クロスヘアシートの交換前後の評価する機会を 得たため, 本研究の方法によって評価を行った。

\section{1. 方 法}

\section{1-1 水ファントムの設置}

放射線治療装置 Clinac iX (Varian Medical Systems, Inc., Palo Alto, CA, USA)を用いて, 光照射野とX線 照射野の測定を行った。射出方向は, ディジタル水平 器 (シンワ測定株式会社, 新潟)を用いて, 垂直方向に $\mathrm{X}$ 線が照射されるようにガントリの幾何学的角度を 調整した. 三次元水ファントムには MP3 (PTWFreiburg GmbH, Freiburg, Germany) を使用し, AAPM TG-106 ${ }^{13)}$ に従って, 水面と駆動軸の水平が一 致するようにファントムの傾きを調整した。決定され た水ファントム位置を, ファントム壁面に映るレーザ 位置で記録した，次に，水ファントム内から水を抜 き, 空中測定ができるようにした。この際, 空の水 ファントムの位置ズレが予想されるため, 前述のファ ントム壁面に記録されたレーザ位置の印を確認し, ファントム位置や角度の調整を行った. 三次元水ファ

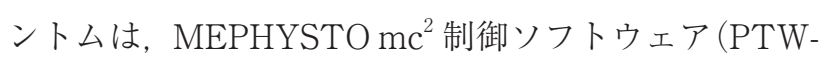
Freiburg GmbH)によって動作された。

\section{1-2 光照射野の測定}

Figure 1aのように, 空の水ファントム内に有感体 積が $7 \mathrm{~mm}^{3}$, 有感検出領域幅が約 $1.5 \mathrm{~mm}$ の光プロー ブ検出器 model 9311(PTW-Freiburg GmbH) を設置し た.この光プローブ検出器は, PTW 社が商品説明時 のデモンストレーション用として開発された測定器で あり, 一般には販売されていない. 検出器の形状は, semiflex 型電離箱線量計 31010 (PTW-Freiburg $\mathrm{GmbH}$ ) と同等の幾何学的外観を有している. 電位計 には, TANDEM dual channel electrometer T10011 (PTW-Freiburg GmbH) を用い, ケーブル接続は $\mathrm{M}$ 型 


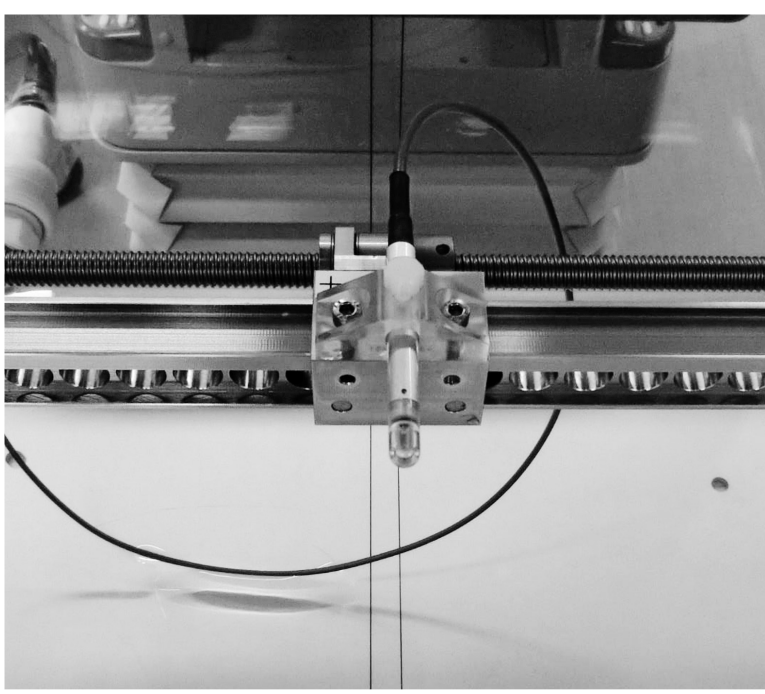

Fig. 1 Experimental setup for field measurements.

(a) Arrangement of the light probe detector in measuring light field

(b) Arrangement of the ionization chamber in measuring X-ray field

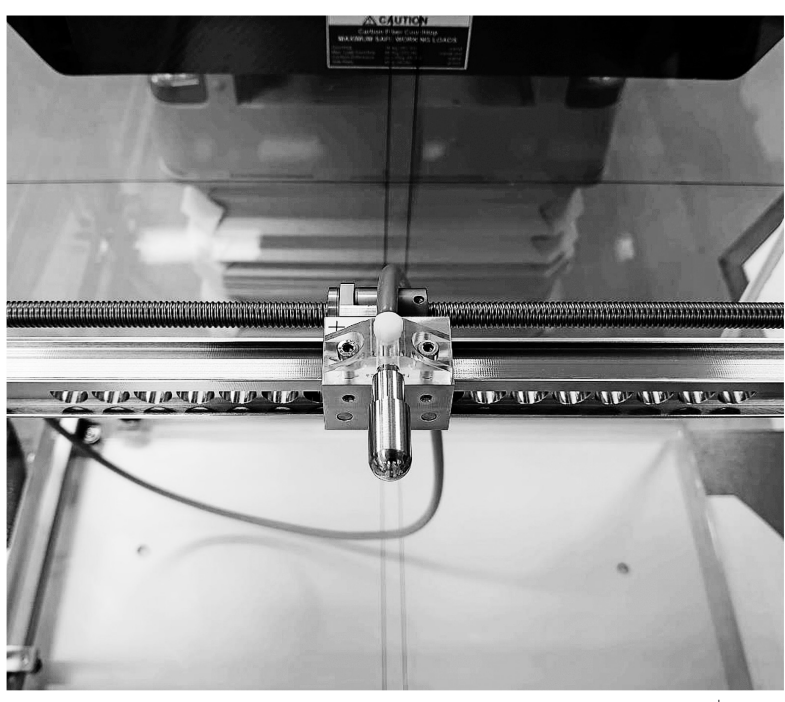

a $\quad b$
Field aperture (Beams eye view)

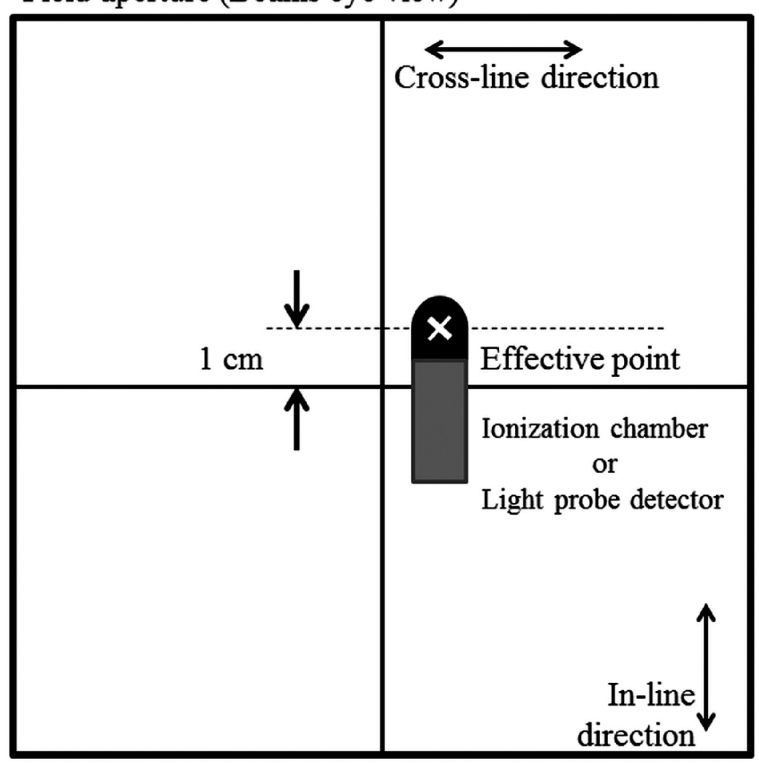

Fig. 2 Measurement position and directions of the detector shown from the beam emission perspective.

を用いている. 印加電圧はメーカ推奨の $0 \mathrm{~V}$ とした 検出器設置位置は，有感体積の中心を測定点に合わせ て測定を行った。治療装置の表示光や治療室内光を暗 幕でカバーし, 光照射野の可視光のみが検出器に入射 されるようにして測定を行った。本研究で使用された 治療装置 Clinac iX には，光照射野が照射された場合 に，中心位置を示すための買書き線が描かれたクロス ヘアシート (以下，シート)が射出口部分に装備されて いる，そのため，羁書き線の影を避けるように，光プ ローブ検出器の設置位置は, 中心位置から $1 \mathrm{~cm}$ シフ
トされた状態で測定された (Fig. 2)。検出器の有感体 積の中心が，治療装置のビーム軸に垂直で X 線ター ゲット位置から $100 \mathrm{~cm}$ の距離平面 (アイソセンタ面) 上に一致するように設置された。測定間隔は $1 \mathrm{~mm}$ 間隔とし，光照射野を照らしたままの状態で，三次元 水ファントムによるスキャニング測定を行い, 光プ ローブ検出器の表示值を記録した。スキャニング測定 法はStep by Step 法により, 測定点当たり 2.0 秒の データ収集時間で測定された。光照射野は，二次コリ メータで既定された 50×50，100×100，200×200 mm² 正 方形照射野で測定された。それぞれの照射野につい て, 検出器をビーム軸に垂直な方向へ動作させ, cross-line 方向と in-line 方向についてデータを取得し た。取得デー夕は 3 回測定を行い，平均值を軸外光量 比の測定值とした。

本研究では, 得られた軸外光量比から FWHM を算 出し, 空中における光照射野幅と定義した。また,

IEC 60976 \%)参考にし，80\%光量位置と 20\%光量位 置の幅を半影幅と定義した. IEC 609769) で定義され る平坦化領域内に扔ける平坦度および対称性の評価を 行った。 シートの有無における光照射野への影響を調 査するため, シートのない状態に扔ける評価も行っ た。更に，シート交換後の調査を同様に行った。

\section{1-3 X 線照射野の測定}

$X$ 線照射野と光照射野とを比較するため, 光プロー ブ検出器と同じ位置に, semiflex 型電離箱線量計を設 
置してX 線照射野の測定を行った，光プローブ検出 器に近い有感領域直径をもつ semiflex 型電離箱線量 計 31016 (PTW-Freiburg GmbH) (有感体積 $0.016 \mathrm{~cm}^{3}$, 有感領域直径 $1.45 \mathrm{~mm})^{14)}$ にアルミニウム製ビルド アップキャップを装着して測定を行った。電離箱線量 計 31016 を, Fig. 1bのように空の三次元水ファント ム内に設置した。また, 電離箱線量計は電位計 T10011に接続され，-400 V が印加された。軸外線量 比は, 光照射野と同様に，X線のビーム軸に対して垂 直な方向に電離箱を走査することにより取得された。 測定間隔は $1 \mathrm{~mm}$ とし, 測定法はStep by Step 法によ り取得した。測定点当たりの測定時間は 1.0 秒であ る，光照射野と同一位置において比較するために，羁 書き線の中心位置から $1 \mathrm{~cm}$ シフトした位置に扮いて 測定を行った (Fig. 2)，X線の照射条件は，光照射野 の測定に合わせて, 正方形照射野 $50 \times 50,100 \times 100$, $200 \times 200 \mathrm{~mm}^{2}$ とし, 線量率は $600 \mathrm{MU} / \mathrm{min}$ とした。
得られた軸外線量比から FWHM を算出し, 空中に おけるX 線照射野幅と定義した。また，IEC 60976 を参考にし, $80 \%$ 線量位置と $20 \%$ 線量位置の幅を半影 幅と定義した，IEC 60976 ${ }^{9)}$ で定義される平坦化領域 内に打ける平坦度扮よび対称性について評価を行っ た。シートの有無におけるX 線照射野への影響を調 査するため, シートのない状態における評価も行っ た。 また，シート交換後の調査を同様に行った。

\section{2. 結 果}

Figure 3〜 5 は, シート交換後の, 各照射野の大きさ に扔ける光照射野の軸外光量比と $6 \mathrm{MV}$ X 線照射野の 軸外線量比を示している。10 MV X 線に関しては，6 MV X 線のプロファイルと重なるため, $6 \mathrm{MV} \mathrm{X}$ 線の 軸外線量比のみ掲載した. Figure 3〜 5のように, 光 照射野は, 光量の多い領域において值のばらつきが大 きく, ゼロ位置では羁書き線の影によって光量が急激
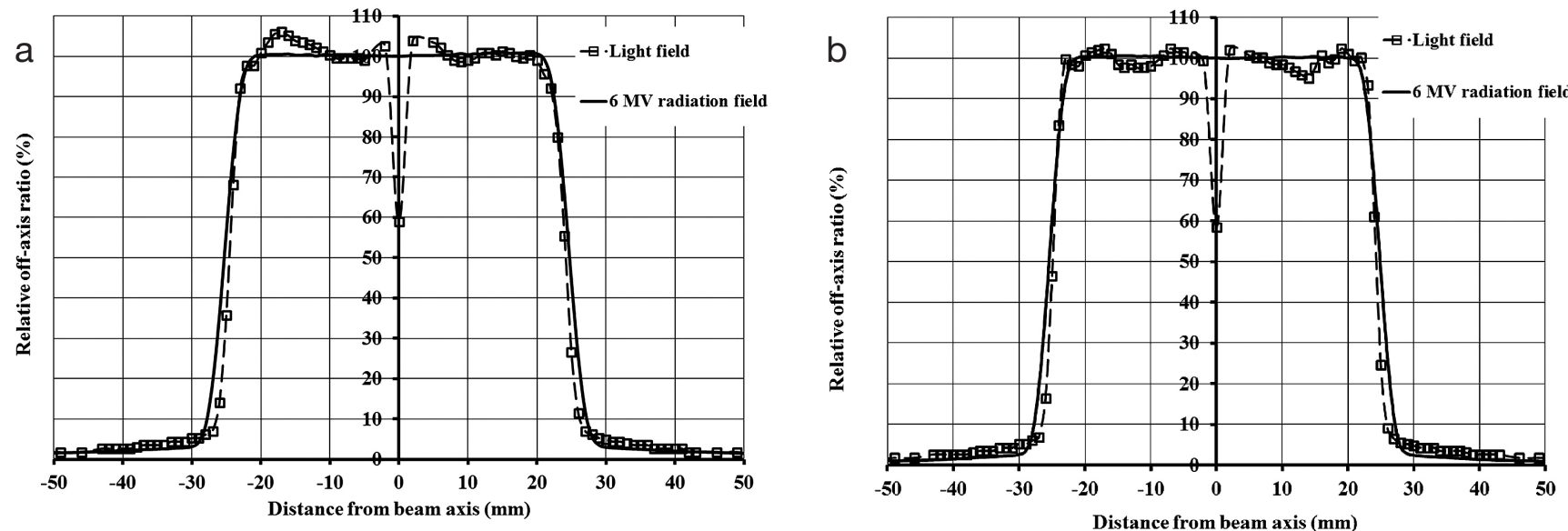

Fig. 3 Measurements of light and X-ray fields according to the distance from the beam axis in a geometrical field of $50 \times 50 \mathrm{~mm}^{2}$. (a) In-line, (b) Cross-line direction
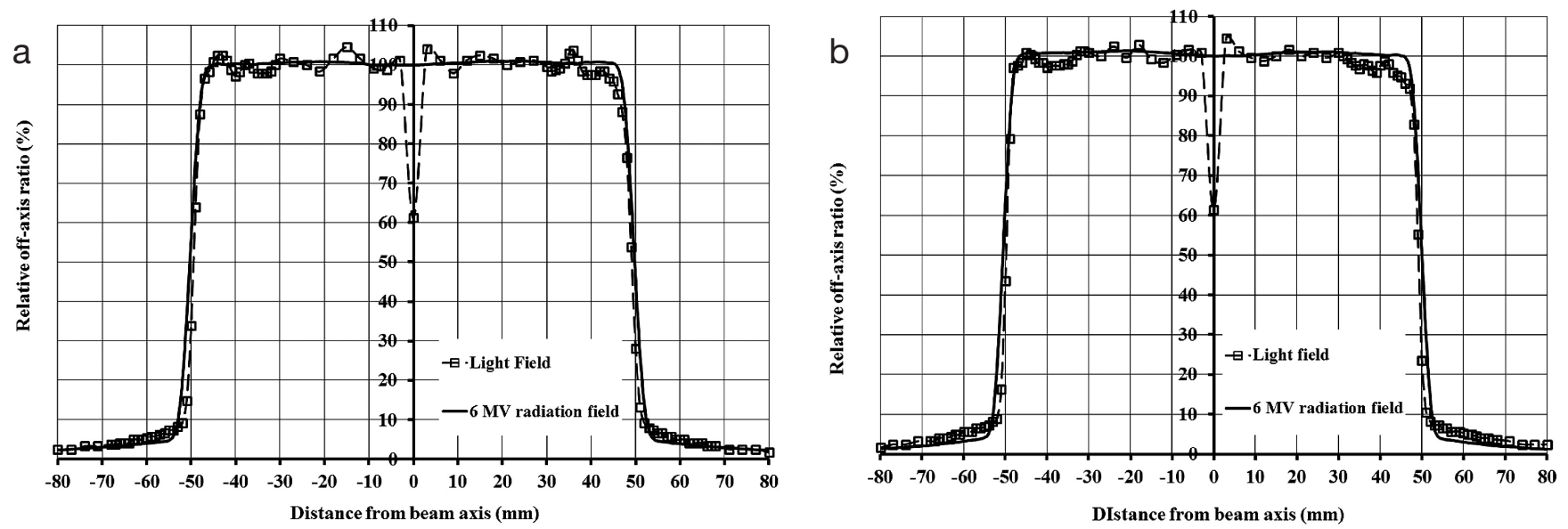

Fig. 4 Measurements of light and X-ray fields according to the distance from the beam axis in a geometrical field of $100 \times 100 \mathrm{~mm}^{2}$. (a) In-line, (b) Cross-line direction 

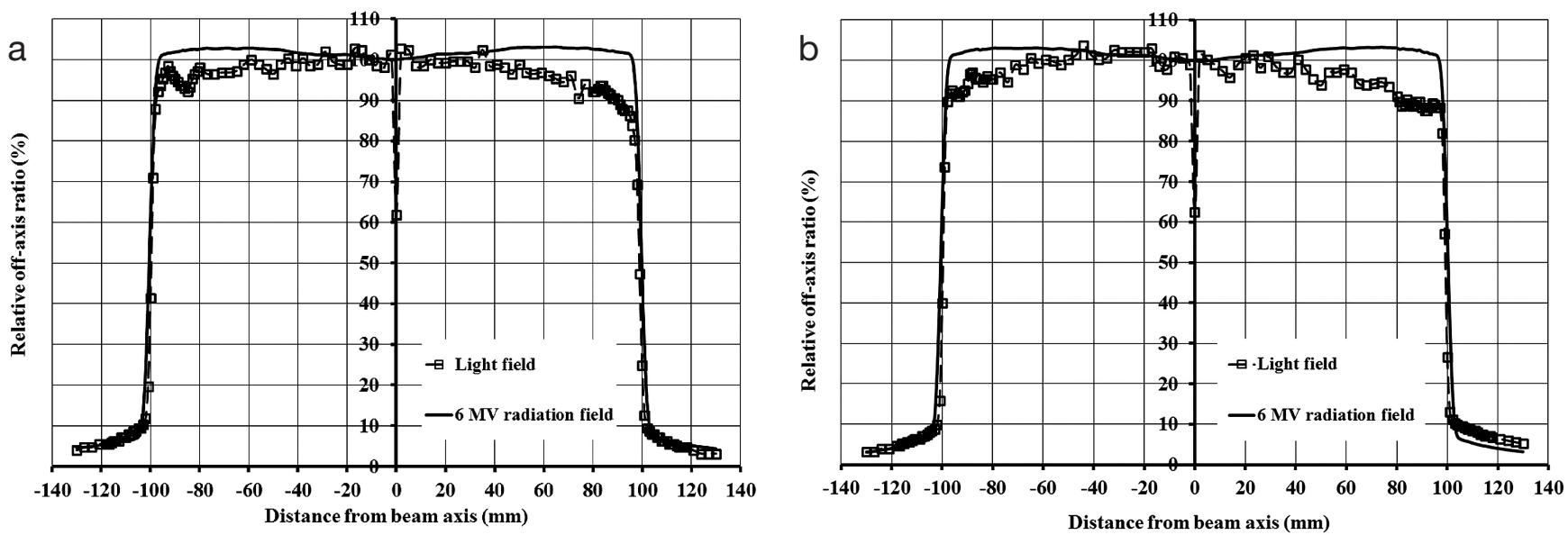

Fig. 5 Measurements of light and X-ray fields according to the distance from the beam axis in a geometrical field of $200 \times 200 \mathrm{~mm}^{2}$. (a) In-line, (b) Cross-line direction

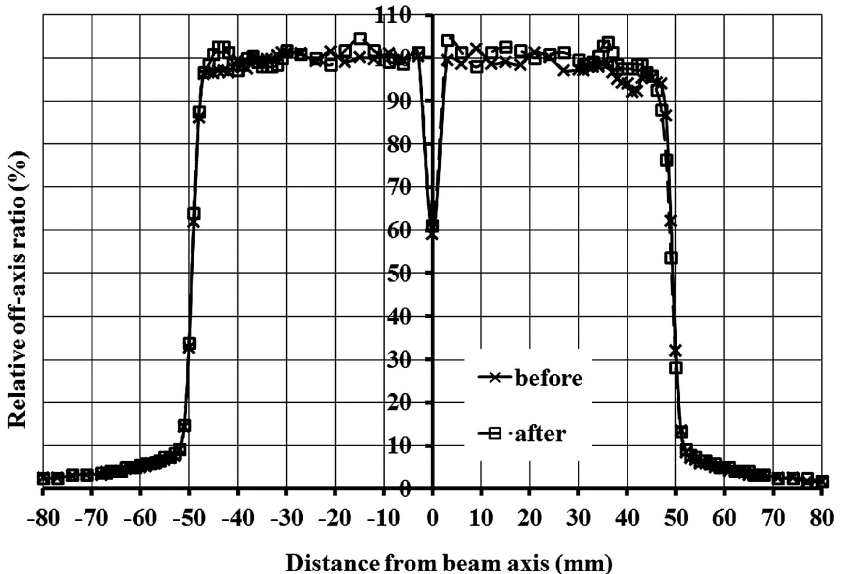

Fig. 6 Measurements of light field along the in-line direction before and after crosshair exchange in geometrical field of $100 \times 100 \mathrm{~mm}^{2}$.

に落ちている。そのため, ビーム軸外の 10-20 mm 範 囲の光量の平均值で正規化された值でプロファイルグ ラフを作成し軸外光量比とした。また，Fig. 6 にシー 卜交換前後の in-line 方向の光照射野の軸外光量比を 示した。

各照射野の大きさで得られた平坦度の平均值は, 光 照射野では 1.71 となった。シートのない状態におけ る平坦度の平均值 1.08 に対して $57.3 \%$ の変化率で あった。また，シート交換前に対する変化率は-1.4\% であった，同様に，対称性の平均值に関しては光照射 野では 1.01 となり，シートのない状態に対する変化率 は $0.7 \%$ であった，交換前との比較においては $1.0 \%$ と なった。照射野 200×200 mm²では，ビーム軸から離 れるにつれて光量の減少がみられた影響により, 平坦 度值が大きくなる傾向であった，X線照射野の平坦 度の平均值は 1.02 となり, シートのない状態と比較し
て $0.1 \%$ の変化率であった。また，シート交換前後に おいても $0.1 \%$ と大きな差がなく，シートの有無およ び交換による影響は少なかった。

測定された軸外光量比および軸外線量比から算出さ れた照射野の半值幅(FWHM) と両者の差を, Table 1 に示した。アイソセンタ面の空中における光照射野幅 FWHM は, 治療装置に入力された照射野の幾何学的 設定表示值より小さい值となり，その残差は in-line 方 向では-1.4 $\pm 0.1 \mathrm{~mm}$ (平均值標準偏差), cross-line 方

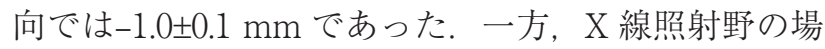
合は, $6 \mathrm{MVX}$ 線において in-line 方向で+0.2 $0.2 \mathrm{~mm}$,

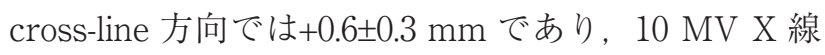
ではそれぞれ+0.3 $\pm 0.3 \mathrm{~mm},+0.7 \pm 0.3 \mathrm{~mm}$ であった。照 射野 $100 \times 100 \mathrm{~mm}^{2}$ 以下については, いずれも幾何学 的表示值から $1 \mathrm{~mm}$ 以下の差であった。光照射野と $\mathrm{X}$ 線照射野の最大ズレ量は，照射野 $200 \times 200 \mathrm{~mm}^{2}$ に おいて $6 \mathrm{MV} \mathrm{X}$ 線で in-line 方向で $1.8 \mathrm{~mm}$, cross-line 方向で $2.0 \mathrm{~mm}, 10 \mathrm{MV} \mathrm{X}$ 線ではそれぞれ $2.1 \mathrm{~mm}, 2.2$ $\mathrm{mm}$ であった。

軸外光量比および軸外線量比から得られた各照射野 の半影幅平均值を Table 2 に示した。半影幅平均值に ついては, in-line 方向では $\mathrm{X}$ 線焦点 $(\mathrm{T})$ 側と電子銃 (G) 側の半影幅の平均值, cross-line 方向では左 $(\mathrm{L})$ 側 と右 $(\mathrm{R})$ 側の半影幅の平均值とした。光照射野の場合 は, 半影幅は in-line 方向で $2.6 \pm 0.3 \mathrm{~mm}$, cross-line 方 向で $2.1 \pm 0.2 \mathrm{~mm}$ であり, 照射野の増加に伴ってそれ ぞれの方向で $0.6 \mathrm{~mm}, 0.5 \mathrm{~mm}$ 増加した. それに対し て，X 線照射野においては，6 MV X 線での半影幅は in-line 方向で $3.0 \pm 0.0 \mathrm{~mm}$, cross-line 方向で $3.6 \pm 0.2$ $\mathrm{mm}$ であり, 照射野の増加に伴ってそれぞれの方向で $0.2 \mathrm{~mm}, 0.1 \mathrm{~mm}$ の増加であった. $10 \mathrm{MV} \mathrm{X}$ 線の半影 
Table 1 FWHM values obtained from the profiles of measured light and radiation fields per energy level and their width difference

\begin{tabular}{|c|c|c|c|c|c|c|}
\hline \multirow{2}{*}{ Geometrical field } & & \multirow{2}{*}{$\begin{array}{l}\text { Light } \\
\text { Field }\end{array}$} & \multicolumn{2}{|c|}{6 MV X-ray } & \multicolumn{2}{|c|}{10 MV X-ray } \\
\hline & & & Field & Width difference & Field & Width difference \\
\hline \multirow[t]{2}{*}{$50 \times 50$} & In-line & 48.7 & 50.0 & -1.3 & 50.1 & -1.4 \\
\hline & Cross-line & 49.2 & 50.3 & -1.1 & 50.4 & -1.2 \\
\hline \multirow[t]{2}{*}{$100 \times 100$} & In-line & 98.6 & 100.1 & -1.5 & 100.2 & -1.6 \\
\hline & Cross-line & 99.0 & 100.6 & -1.6 & 100.7 & -1.7 \\
\hline \multirow[t]{2}{*}{$200 \times 200$} & In-line & 198.6 & 200.4 & -1.8 & 200.7 & -2.1 \\
\hline & Cross-line & 198.9 & 200.9 & -2.0 & 201.1 & -2.2 \\
\hline
\end{tabular}

Every value is expressed in millimeters.

Table 2 Penumbra width in the in-line direction and the cross-line direction after the crosshair sheet exchange

\begin{tabular}{ccccccccc}
\hline \hline \multirow{2}{*}{ Geometrical field } & \multicolumn{2}{c}{ Light } & & \multicolumn{2}{c}{6 MV X-ray } & & \multicolumn{2}{c}{10 MV X-ray } \\
\cline { 2 - 3 } & $\begin{array}{c}\text { In-line } \\
\text { mean }\end{array}$ & $\begin{array}{c}\text { Cross-line } \\
\text { mean }\end{array}$ & & $\begin{array}{c}\text { In-line } \\
\text { mean }\end{array}$ & $\begin{array}{c}\text { Cross-line } \\
\text { mean }\end{array}$ & & $\begin{array}{c}\text { In-line } \\
\text { mean }\end{array}$ & $\begin{array}{c}\text { Cross-line } \\
\text { mean }\end{array}$ \\
\hline $50 \times 50$ & 2.3 & 1.8 & & 3.2 & 3.0 & & 3.5 & 3.3 \\
$100 \times 100$ & 2.6 & 2.0 & & 3.3 & 3.1 & & 3.6 & 3.4 \\
$200 \times 200$ & 2.9 & 2.3 & & 3.4 & 3.1 & & 3.8 & 3.5 \\
\hline Mean & 2.6 & 2.1 & & 3.3 & 3.0 & & 3.6 & 3.4 \\
SD & 0.3 & 0.2 & & 0.1 & 0.0 & & 0.2 & 0.1 \\
\hline
\end{tabular}

Every value is expressed in millimeters.

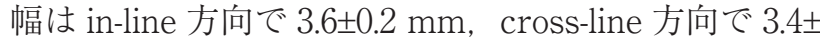
$0.1 \mathrm{~mm}$ であり，それぞれの方向で $0.3 \mathrm{~mm}, 0.2 \mathrm{~mm}$ の増加であった，半影幅は，光照射野では in-line 方向 は cross-line 方向より約 $0.5 \mathrm{~mm}$ 大きく, X 線照射野 では約 $0.3 \mathrm{~mm}$ 大きかった。光照射野は $6 \mathrm{MV} \mathrm{X}$ 線照 射野と比較すると, in-line 方向で $0.7 \pm 0.4 \mathrm{~mm}$, crossline 方向で $1.0 \pm 0.2 \mathrm{~mm}$ 小さく, 最大差は $1.2 \mathrm{~mm}$ で あった。 $10 \mathrm{MV} X$ 線との比較では，それぞれ $1.0 \pm 0.3$ $\mathrm{mm}, 1.3 \pm 0.2 \mathrm{~mm}$ 小さく, 最大差は $1.5 \mathrm{~mm}$ であった.

\section{3. 考察}

平坦化領域内に打ける光照射野は, ランプ光源に付 着した埃や，シート・透過型ミラーの歪みや污れなど により光量がばらつき, 平坦度の変化に影響している と考えられる. また, 光プローブ検出器の有感部分を 保護するアクリル製キャップにも細かな傷があり，可 視光の乱反射による影響が出現している可能性もあ る。特に，光照射野の平坦度評価において，シートの 有無によって大きく異なる值となったのは，シートに 付着した污れや歪みなどの影響で光量のばらつきが大 きく変化し，值が変化したと考えられる。

光照射野の半影幅が X 線照射野と比べて小さい原 因の一つとして，検出器の有感領域の大きさの違いに
よる影響が考えられるが，本研究では，有感領域直径 がほぼ同等の大きさの電離箱を使用したため,この影 響は考えにくい，主な原因としては，X線が照射され た場合，二次コリメー夕の端の部分における相互作用 の影響で, 平坦化領域外への透過あるいは散乱放射線 が検出され半影幅が広がり, それに伴ってX 線照射 野幅が広がり光照射野との差が広がったと考えられ る. 更に, 光照射野の場合は, 可視光を放出するラン プは等方性光源であるため, 200×200 $\mathrm{mm}^{2}$ のような大 きな照射野では, ビーム軸から離れると, 幾何学的に 光源からの距離が大きくなり, 到達する光量が減少し たものと考えられる。これにより，半影幅の算出值が 大きくなる場合もあった。

In-line 方向の照射野幅は, cross-line 方向の幅に比 べて，光照射野幅・X 線照射野幅ともに小さい值と なった。キャリブレーション時には，水中における SMD の同一アイソセンタ面において, X 軸および $\mathrm{Y}$ 軸二次コリメー夕静止位置を決定する。各軸の二次コ リメータからアイソセンタ面までの距離が異なるた め, 幾何学的な配置の違いにより, アイソセン夕面か らの幾何学的距離の大きいin-line 方向の二次コリ メータの静止位置が狭くなっていると考えられる. シート交換前後の FWHM 值は, 水ファントムの再 
設置誤差や二次コリメータの静止位置誤差による影響 が含まれており，最大で $0.4 \mathrm{~mm}$ の差が生じた. 光照 射野については平坦化領域内における光量のばらつき は同様に出現した。

本研究において, 光照射野と $X$ 線照射野の最大差 は, $6 \mathrm{MV} \mathrm{X}$ 線で $2.0 \mathrm{~mm}, 10 \mathrm{MVX}$ 線で $2.2 \mathrm{~mm}$ と なった。これらの結果は, Johnsen ら ${ }^{12)}$ の結果と似た 傾向を示している。本研究では, スキャン方向の違い や X 線エネルギーの違いによる評価も加え, より詳 細なデータとして提供することができた，JASTRO ガイドライン ${ }^{5)}$ や A APM TG-142 $2^{7)}$ によると, 光照射 野と X 線照射野の一致度の許容誤差として $2 \mathrm{~mm}$ が 推奨されている。本研究における結果は，ガイドライ ンの推奨值を超えていた。同一位置・同一幾何学的照 射野において測定しても，可視光波長領域とX 線波 長領域の電磁波では二次コリメータの端 Fig などにお ける相互作用の違いや，光源およびX 線焦点の大き さの違いやビームの広がり方の違いがあるため, 理論 的に一致はしない. 各ガイドラインで提案されている 両者の照射野一致性について, 異なる性質の照射野の 一致度を，正確に評価することは困難であると考えら れる。われわれの提案する品質管理手法は, 装置導入 時にNTDのSMD における水中の X 線照射野幅から 二次コリメータ静止位置が決定された状態で, 本研究 で用いた手法で光照射野およびX 線照射野の測定值 を基準とし，定期的に測定をすることで，両者の照射
野一致度の評価を, 経時的で定量的に管理することを 可能にする.

\section{4. 結 語}

本研究では, 光プローブ検出器を用いて, 定量的で 経時的な光照射野の測定の可能性を提案した. 空の三 次元水ファントムを使用することで，空中における光 照射野と同一位置におけるX 線照射野の測定を行い, 一致度を定量的に評価することができた。これまで, 視覚的評価されてきた光照射野の測定について, 光プ ローブ検出器を用いることにより，測定者間誤差を軽 減することを可能にした。検出器の特性として，水中 における評価が困難であるため, 正確な照射野幅の測 定は不可能であるが, 基準值から経時的な变化を点検 することは可能である。

\section{謝 辞}

本研究に際し, 施設の放射線治療装置を使用させて いたたききした名古屋大学医学部附属病院の皆様へ感 謝申し上げます。

なお, 本研究の要旨は日本医学物理学会第 115 回学 術大会 $(2018$ 年, 横浜)にて発表した。

\section{利益相反}

筆頭著者および共著者が開示すべき利益相反はない.

\section{参考文献}

1）榮 武二, 櫻井英幸 監修. 放射線治療 基礎知識図解ノー 卜，東京：金原出版，2016.

2) 日本放射線腫瘍学会, 日本放射線腫瘍学研究機構 編. 臨 床放射線腫瘍学 最新知見に基づいた放射線治療の実践. 東京：南江堂, 2012.

3）日本放射線技術学会 監修. 放射線技術学シリーズ 放射 線治療技術学(改訂 2 版)。東京：オーム社，2016.

4）熊谷孝三 編．わかりやすくてためになる がん放射線治 療技術マニュアル．東京：ピラールプレス，2011．

5）日本放射線腫瘍学会 QA 委員会 編. 外部放射線治療にお ける Quality Assurance (QA) システムガイドライン。日放 線腫瘍会誌 2000; 11(suppl 2).

6) Svensson GK, Baily NA, Loevinger R, et al. AAPM Report No. 13: Physical aspects of quality assurance in radiation therapy. AAPM Radiation Therapy Committee Task Group No. 24. American Association of Physicists in Medicine, 1994.

7) Klein EE, Hanley J, Bayouth J, et al. Task Group 142 report: quality assurance of medical accelerators. Med Phys 2009; 36 (9): 4197-4212.

8) Nath R, Biggs PJ, Bova FJ, et al. AAPM code of practice for radiotherapy accelerators: report of AAPM Radiation Therapy
Task Group No. 45. Med Phys 1994; 21(7): 1093-1121.

9) International Electrotechnical Commission. IEC 60976 International Standard: Medical electrical equipment-medical electron accelerators-functional performance characteristics. Edition 2.0. Geneva: IEC, 2007.

10）日本放射線腫瘍学会研究調査委員会 編. 外部放射線治療 装置の保守管理プログラム。東京：通商産業研究社, 2001.

11) 日本放射線技術学会 編. 放射線医療技術学叢書 (22) 外 部放射線治療に扮ける保守管理マニュアル 日本放射線 技術学会出版委員会, 2003.

12) Johnsen SW, Hamm RW. An improved technique for aligning the light field with the radiation fields on radiotherapy accelerators. Med Phys 1988; 15(2): 267-268.

13) Das IJ, Cheng CW, Watts RJ, et al. Accelerator beam data commissioning equipment and procedures: report of the TG106 of the Therapy Physics Committee of the AAPM. Med Phys 2008; 35(9): 4186-4215.

14) PTW-Freiburg. Ionizing radiation detectors including codes of practice. Freiburg: PTW-Freiburg, 2014.

問合先 